\title{
The Development Analysis of Chinese Intangible Cultural Heritage Representative List
}

\author{
YE Peng, ZHOU Yao-lin \\ School of information management, Wuhan University, Wuhan, China \\ Ye.peng@whu.edu.cn, zhouyaolin@whu.edu.cn
}

\begin{abstract}
Papers expounded the Chinese intangible cultural heritage list system by quantitative statistics and data analysis. According to the existing results and protection systems of Chinese intangible cultural heritage representative list, it puts forward development problems and key points for solution.

Index Terms - China, intangible cultural heritage, development analysis, list
\end{abstract}

\section{Introduction}

"Human oral and non-material heritage representative work list" was announced by UNESCO on May 18, 2001. In October 2003, the 32nd session of the UNESCO conference through the convention on the protection of intangible cultural heritage, explicitly proposed "the human intangible cultural heritage representative work list" and "urgently needs to protect the intangible cultural heritage list" for the construction of the rules. The series of UNESCO conferences pushed the governments paid more attention to protect national intangible cultural heritage in their counties.

As one of the contracting parties, the Chinese government promised to protect and inherit the outstanding human culture. The government also promoted the sustainable development of human society from the aspects of social, economic and legal environment in China. So far, there were 217 projects in the human intangible cultural heritage representative work list from about 140 countries. 27 projects from 16 countries were listed in the need to protect the intangible cultural heritage list. Among them, 29 projects were listed as human intangible cultural heritage representative work list in China, such as the Chinese Dragon Boat Festival, Chinese calligraphy, paper cutting, the traditional wooden construction techniques. 7 projects were listed as the need to protect the non-material cultural heritage list in China, such as spun silk embroideries tradition of $\mathrm{Li}$ nationality, Chinese traditional wooden arch bridge construction techniques.

Nowadays, China has become the most populous nation in the world human intangible cultural heritage representative work list.

\section{The Developing Course of Chinese Intangible Cultural Heritage Representative List}

In the early 1950's, the Chinese government had organized organizations and experts to investigate the minority cultural heritages in China, then taken measures to protect and nurture a large number of traditional arts and crafts industry. The government named 200 people as the national arts and crafts masters [1]. This was the beginning of the heritage protection in China.

From then on, the Chinese intangible cultural heritage protection works have carried out in China(Table I ).

TABLE I The Protection Efforts of Chinese Intangible Heritage Projects

\begin{tabular}{|c|c|}
\hline Year & Key events \\
\hline 1979 & $\begin{array}{l}\text { inistry of culture, State ethnic affairs commission, China federation of literary and art circles had jointly initiated compilation work of "China national folk literature and art } \\
\text { ooks", More than } 30 \text { years, hundreds of cultural workers participated in writing the series books. In } 2010 \text {, the ten sets of books were completed and contained } 298 \text { volumes of } \\
95 \text { of the } 450 \text { million words in total [2]. }\end{array}$ \\
\hline 2003 & $\begin{array}{l}\text { te ethnic affairs commission, Ministry of culture, Ministry of finance, and China federation of literary and art circles had jointly launched the Chinese national folk culture } \\
\text { otection project. The project plan cost } 17 \text { years. By } 2020 \text {, China will preliminarily establish a relatively complete intangible cultural heritage protection system. }\end{array}$ \\
\hline 2004 & $\begin{array}{l}\text { inistry of culture, Ministry of finance had jointly issued "Chinese folk culture protection plan". It was the first time to draw up a plan for establishing a national folk culture } \\
\text { otection list. }\end{array}$ \\
\hline 2006 & $\begin{array}{l}\text { e state council of China had issued a decree which named as "The first batch of national level intangible cultural heritage list". It marked the first batch of national level } \\
\text { tangible cultural heritage project formally established, which involving } 758 \text { units to be protected, covers } 518 \text { national catalogue. }\end{array}$ \\
\hline 2007 & $\begin{array}{l}\text { hina had carried out the first intangible cultural heritage census all over the country. The work was a scientific, comprehensive, systematic foundation for Chinese national } \\
\text { tangible cultural heritage system. }\end{array}$ \\
\hline 2008 & $\begin{array}{l}\text { hinese intangible cultural heritage protection had made a breakthrough. The "Level } 4 \text { protection list system" has been gradually established. At the same year, the government } \\
\text { so set up the "Intangible cultural heritage inheritance person protection system" and effectively promoted the "Cultural heritage awareness day". }\end{array}$ \\
\hline 2009 & $\begin{array}{l}\text { e CPC central committee and the state council of China had jointly issued a number of important documents, which established principles and tasks about intangible cultural } \\
\text { eritage protection works in China. The documents determined the "Level } 4 \text { protection list system", which included national level, provincial level, city level and country level. } \\
\text { he system included naming, awarding, commendation, reward and others ways for protecting intangible cultural heritage and representative inheritance persons in China. }\end{array}$ \\
\hline 2010 & $\begin{array}{l}\text { The first intangible cultural heritage census was over. The census cost about } 800 \text { million CNY and held more than } 71,000 \text { times symposiums, visited more than } 1.15 \text { million folk } \\
\text { artists, collected about } 290,000 \text { projects of precious objects and information, written } 9.96 \text { million words of census, made } 234,000 \text { hours audio records, } 183,000 \text { hours video } \\
\text { records, } 4.774 \text { million pieces of camera shootings, more than } 142,000 \text { copies of compiled census data. The first intangible cultural heritage census counted more than } 970,000 \\
\text { projects of intangible cultural heritage in China [3]. }\end{array}$ \\
\hline 2011 & $\begin{array}{l}\text { "The intangible cultural heritage law" was enacted in China. It put forward normative requirements of intangible cultural heritage protection as three aspects, which include } \\
\text { survey system, directory system and transmission system. The law especially specified intangible cultural heritage representative projects in the chapter } 3 \text {. It marked that } \\
\text { Chinese intangible cultural heritage protection took to a legal orbit. }\end{array}$ \\
\hline 2012 & (1) \\
\hline
\end{tabular}




\section{The Developing Efforts of Chinese Intangible Cultural Heritage Representative List}

\section{A. Projects Lists}

Ministry of culture established the national level intangible cultural heritage representative list which must be from the provincial level. And the provincial intangible cultural heritage representative list must be from city level or country level.

In 2006, 2008 and 2011, the state council announced three batches of national level intangible cultural heritage list, a total of 1,219 projects(Table II). The system of national, provincial, city and county level list has been basically formed. From total view, Chinese governments at all levels have issued 8,786 provincial intangible cultural heritage project(Table III), 18,186 city level intangible cultural heritage projects and 53,776 county level intangible cultural heritage project [4].

For the current data of Chinese intangible cultural heritage projects, there have been more than 70,000 projects in the 4 level intangible cultural heritage protection systems [5]. But it only occupied $7 \%$ in the total 970,000 projects of Chinese intangible cultural heritage resources. From these data, we can know the Chinese intangible cultural heritage resources have a large exploring space and a serious protection pressure.

TABLE II The National Level of Chinese Intangible Cultural Heritage Projects

\begin{tabular}{|c|c|c|c|c|}
\hline Element & $\begin{array}{c}\text { The 1st } \\
\text { batch }\end{array}$ & $\begin{array}{c}\text { The 2nd } \\
\text { batch }\end{array}$ & $\begin{array}{c}\text { The 3rd } \\
\text { batch }\end{array}$ & $\begin{array}{c}\text { The 4th } \\
\text { batch }\end{array}$ \\
\hline Folk literature & 31 & 53 & 41 & 125 \\
\hline The traditional music & 72 & 67 & 16 & 155 \\
\hline Traditional dance & 41 & 55 & 15 & 111 \\
\hline Traditional operas & 92 & 46 & 20 & 158 \\
\hline Traditional art & 51 & 45 & 13 & 109 \\
\hline Traditional skills & 89 & 97 & 26 & 212 \\
\hline Traditional medicine & 9 & 8 & 4 & 21 \\
\hline shuochang & 46 & 50 & 18 & 114 \\
\hline Folk customs & 70 & 51 & 23 & 144 \\
\hline $\begin{array}{c}\text { Traditional sports, } \\
\text { recreational and acrobatics }\end{array}$ & 17 & 38 & 15 & 70 \\
\hline Total & 518 & 510 & 191 & 1219 \\
\hline
\end{tabular}

According to the state council published data sorting
TABLE III The Provincial Level of Chinese Intangible Cultural Heritage Projects

\begin{tabular}{|c|c|c|c|c|c|c|}
\hline Rank & Province & \begin{tabular}{|c|} 
The 1st \\
batch
\end{tabular} & $\begin{array}{c}\text { The } 2 \text { nd } \\
\text { batch }\end{array}$ & $\begin{array}{c}\text { The 3rd } \\
\text { batch }\end{array}$ & $\begin{array}{c}\text { The 4th } \\
\text { batch }\end{array}$ & Total \\
\hline 1 & Zhejiang province & 64 & 225 & 246 & 202 & 737 \\
\hline 2 & Hebei province & 130 & 97 & 139 & 111 & 477 \\
\hline 3 & Guizhou province & 91 & 202 & 147 & 1 & 440 \\
\hline 4 & Sichuan province & 189 & 137 & 89 & I & 415 \\
\hline 5 & Henan province & 148 & 129 & 95 & I & 372 \\
\hline 6 & Jiangxi province & 62 & 102 & 206 & 1 & 370 \\
\hline 7 & Shaanxi province & 145 & 100 & 116 & I & 361 \\
\hline 8 & Guangdong province & 78 & 104 & 123 & 52 & 357 \\
\hline 9 & Fujian province & 101 & 98 & 82 & 73 & 354 \\
\hline 10 & Shanxi Province & 105 & 141 & 82 & 1 & 328 \\
\hline 11 & $\begin{array}{l}\text { The Tibet autonomous } \\
\text { region }\end{array}$ & 38 & 83 & 101 & 101 & 323 \\
\hline 12 & Shandong province & 157 & 150 & / & l & 307 \\
\hline 13 & $\begin{array}{l}\text { The guangxi zhuang } \\
\text { autonomous region }\end{array}$ & 58 & 63 & 86 & 98 & 305 \\
\hline 14 & $\begin{array}{l}\text { Inner Mongolia } \\
\text { autonomous region }\end{array}$ & 140 & 111 & 48 & l & 299 \\
\hline 15 & Jiangsu province & 123 & 112 & 63 & I & 298 \\
\hline 16 & Chongqing city & 62 & 97 & 119 & I & 278 \\
\hline 17 & Yunnan province & 147 & 124 & 1 & I & 271 \\
\hline 18 & Gansu province & 85 & 88 & 91 & I & 264 \\
\hline 19 & Anhui province & 83 & 90 & 81 & I & 254 \\
\hline 20 & Hubei province & 97 & 66 & 90 & I & 253 \\
\hline 21 & $\begin{array}{l}\text { The xinjiang uygur } \\
\text { autonomous region }\end{array}$ & 108 & 77 & 52 & I & 237 \\
\hline 22 & Beijing city & 48 & 105 & 59 & / & 212 \\
\hline 23 & Hunan province & 74 & 84 & 50 & 1 & 208 \\
\hline 24 & Liaoning province & 60 & 54 & 41 & 35 & 190 \\
\hline 25 & Heilongjiang province & 57 & 79 & 47 & 1 & 183 \\
\hline 26 & Jilin province & 75 & 105 & l & I & 180 \\
\hline 27 & Shanghai city & 83 & 45 & 29 & I & 157 \\
\hline 28 & Qinghai province & 33 & 69 & 48 & 1 & 150 \\
\hline 29 & Tianjin city & 30 & 50 & I & 1 & 80 \\
\hline 30 & Hainan province & I & I & l & 72 & 72 \\
\hline 31 & $\begin{array}{l}\text { The ningxia hui } \\
\text { autonomous region }\end{array}$ & 31 & 23 & / & l & 54 \\
\hline 32 & Taiwan province & I & I & I & I & I \\
\hline 33 & $\begin{array}{l}\text { The Hong Kong } \\
\text { special administrative } \\
\text { region }\end{array}$ & / & / & / & l & I \\
\hline 34 & $\begin{array}{l}\text { The Macao special } \\
\text { administrative region }\end{array}$ & I & / & / & / & l \\
\hline \multicolumn{2}{|c|}{ Total } & 2774 & 3010 & 2330 & 672 & 8786 \\
\hline
\end{tabular}

According to the provincial and city governments published data sorting

\section{B. Representative Inheritance Person Lists}

To strengthen the protection of representative inheritance person, the ministry of culture named four batches national level representative inheritance person lists which included 1986 people(Table IV). And the provincial level representative inheritance person lists also contained 9,564 people. Since 2008, the central government has appropriated $8,000 \mathrm{CNY}$ per person per year for supporting inheritance person to inherit intangible cultural heritage. Since 2011, the subsidy standards have been improved to 10,000 CNY per person per year [6]. 
TABLE IV The Four Batches of National Level of Chinese Representative Inheritance Persons

\begin{tabular}{|l|l|l|l|l|l|l|}
\hline \multicolumn{1}{|c|}{ Element } & $\begin{array}{c}\text { The } \\
1 \text { st } \\
\text { batch }\end{array}$ & $\begin{array}{c}\text { The } \\
\text { 2nd } \\
\text { batch }\end{array}$ & $\begin{array}{c}\text { The } \\
\text { 3rd } \\
\text { batch }\end{array}$ & $\begin{array}{c}\text { The } \\
\text { 4th } \\
\text { batch }\end{array}$ & Total & Proportion \\
\hline Folk literature & 32 & $/$ & 25 & 20 & 77 & $3.8 \%$ \\
\hline $\begin{array}{l}\text { The traditional } \\
\text { music }\end{array}$ & $/$ & 104 & 96 & 31 & 231 & $11.7 \%$ \\
\hline Traditional dance & $/$ & 72 & 56 & 49 & 177 & $8.9 \%$ \\
\hline Traditional operas & $/$ & 304 & 196 & 111 & 611 & $30.8 \%$ \\
\hline Traditional art & 72 & $/$ & 83 & 76 & 231 & $11.7 \%$ \\
\hline Traditional skills & 78 & $/$ & 136 & 112 & 326 & $16.4 \%$ \\
\hline $\begin{array}{l}\text { Traditional } \\
\text { medicine }\end{array}$ & 29 & $/$ & 24 & 21 & 74 & $3.7 \%$ \\
\hline shuochang & $/$ & 66 & 51 & 34 & 151 & $7.6 \%$ \\
\hline Folk customs & $/$ & 5 & 25 & 31 & 61 & $3.0 \%$ \\
\hline $\begin{array}{l}\text { Traditional sports, } \\
\text { recreational and } \\
\text { acrobatics }\end{array}$ & 15 & $/$ & 19 & 13 & 47 & $2.4 \%$ \\
\hline Total & 226 & 551 & 711 & 498 & 1986 & $100 \%$ \\
\hline
\end{tabular}

According to the state council published data sorting

Through the Chinese national level representative inheritance person lists and data analysis, this paper can get the following conclusions.

1) The age structure was obvious too old(Table V): $63.2 \%$ of people distributed form 60 to 90 years old (19201949). Considering the intangible cultural heritage skills need 5-8 years to full inheritance, the government must increasing investment and training speed to reverse the adverse situation of intangible cultural heritage skills.

TABLE V The Age Structure Statistics of National Level of Chinese Representative Inheritance Persons

\begin{tabular}{|l|l|l|l|l|l|l|}
\hline Age Group & $\begin{array}{c}\text { The } \\
\text { 1st } \\
\text { batch }\end{array}$ & $\begin{array}{c}\text { The } \\
\text { 2nd } \\
\text { batch }\end{array}$ & $\begin{array}{c}\text { The } \\
\text { 3rd } \\
\text { batch }\end{array}$ & $\begin{array}{c}\text { The } \\
\text { 4th } \\
\text { batch }\end{array}$ & Total & Proportion \\
\hline $\begin{array}{l}\text { And before } \\
1909\end{array}$ & 0 & 1 & 1 & 0 & 2 & $0.1 \%$ \\
\hline $1910-1919$ & 3 & 7 & 2 & 0 & 12 & $0.6 \%$ \\
\hline $1920-1929$ & 44 & 55 & 64 & 39 & 202 & $10.2 \%$ \\
\hline $1930-1939$ & 47 & 122 & 189 & 98 & 456 & $23.0 \%$ \\
\hline $1940-1949$ & 61 & 185 & 246 & 162 & 654 & $33.0 \%$ \\
\hline $1950-1959$ & 52 & 84 & 130 & 99 & 365 & $18.4 \%$ \\
\hline $1960-1969$ & 17 & 83 & 70 & 86 & 256 & $12.8 \%$ \\
\hline $1970-1979$ & 2 & 14 & 9 & 14 & 39 & $1.9 \%$ \\
\hline $\begin{array}{l}\text { In 1980 } \\
\text { and } \\
\text { beyond }\end{array}$ & 0 & 0 & 0 & 0 & 0 & $0 \%$ \\
\hline Total & 226 & 551 & 711 & 498 & 1986 & $100 \%$ \\
\hline
\end{tabular}

According to the state council published data sorting

2) The gender structure was relatively stable(Table VI): The gender structure was more stable. The ratio was stable at 7:3. It showed that the men have more opportunities to contact and learn intangible cultural heritage projects than women in China in history. On the other hand, it also showed that the Chinese government should create more educational opportunities to expand cultural heritage space for women.
TABLE VI The Gender Statistics of National Level of Chinese Representative Inheritance Persons

\begin{tabular}{|l|l|l|l|l|l|}
\hline \multirow{2}{*}{ Batch } & \multicolumn{2}{|c|}{ Male } & \multicolumn{2}{c|}{ Female } & \multirow{2}{*}{ Total } \\
\cline { 2 - 5 } & Number & $\begin{array}{c}\text { Proportio } \\
\mathrm{n}\end{array}$ & Number & $\begin{array}{c}\text { Proportio } \\
\mathrm{n}\end{array}$ & \\
\hline The 1st batch & 184 & $81.4 \%$ & 37 & $18.6 \%$ & 226 \\
\hline The 2nd batch & 401 & $72.7 \%$ & 150 & $27.3 \%$ & 551 \\
\hline The 3rd batch & 542 & $76.2 \%$ & 169 & $23.8 \%$ & 711 \\
\hline The 4th batch & 372 & $74.6 \%$ & 126 & $25.4 \%$ & 498 \\
\hline Total & 1499 & $75.5 \%$ & 482 & $24.6 \%$ & 1986 \\
\hline
\end{tabular}

According to the state council published data sorting

3) Ethnic composition changed significantly(Table VII): The proportion of minority intangible cultural heritage representative person gradually increased from $18.9 \%$ to $26.2 \%$ in the national level of Chinese representative inheritance persons lists. This showed that Chinese government put more attentions on the minority intangible cultural heritage protections. But on the whole, the proportion of minority intangible cultural heritage representative person was also low.

TABLE VII The Ethnic Statistics of National Level of Chinese Representative Inheritance Persons

\begin{tabular}{|c|l|l|l|l|l|}
\hline \multirow{2}{*}{ Batch } & \multicolumn{2}{|c|}{ The Han Nationality } & \multicolumn{2}{c|}{ National Minority } & \multirow{2}{*}{ Total } \\
\cline { 2 - 5 } & Number & $\begin{array}{c}\text { Proportio } \\
\mathrm{n}\end{array}$ & Number & $\begin{array}{c}\text { Proportio } \\
\mathrm{n}\end{array}$ & \\
\hline The 1st batch & 174 & $77 \%$ & 52 & $23 \%$ & 226 \\
\hline The 2nd batch & 447 & $81.1 \%$ & 104 & $18.9 \%$ & 551 \\
\hline The 3rd batch & 534 & $75.1 \%$ & 177 & $24.9 \%$ & 711 \\
\hline The 4th batch & 368 & $73.8 \%$ & 130 & $26.2 \%$ & 498 \\
\hline Total & 1523 & $76.7 \%$ & 463 & $23.3 \%$ & 1986 \\
\hline
\end{tabular}

According to the state council published data sorting

\section{The Trends of Chinese Intangible Cultural Heritage Representative List}

\section{A. Systematic Improvement of intangible cultural heritage representative list}

Intangible cultural heritage was promoted by UNESCO as a counterpart to the World Heritage that focuses mainly on tangible aspects of culture. According to the 2003 Convention for the Safeguarding of the Intangible Cultural Heritage, the intangible cultural heritage was defined as follows: Intangible cultural heritage means the practices, representations, expressions, knowledge, skills - as well as the instruments, objects, artifacts and cultural spaces associated therewith that communities, groups and, in some cases, individuals recognize as part of their cultural heritage [7]. There have been 12 projects belong to "cultural space" class in the UNESCO representative lists of the intangible cultural heritage of humanity (Table VIII). 
TABLE VIII The Statistics of Cultural Space Projects in Human Intangible Cultural Heritage Representative Work List

\begin{tabular}{|c|c|c|c|}
\hline Batch & Year & Element & Member state \\
\hline \multirow{5}{*}{$\begin{array}{l}\text { The } \\
1 \text { st } \\
\text { batch }\end{array}$} & \multirow{5}{*}{2001} & $\begin{array}{l}\text { The Cultural Space of the Brotherhood of } \\
\text { the Holy Spirit of the Congos of Villa } \\
\text { Mella }\end{array}$ & $\begin{array}{l}\text { Dominican } \\
\text { Republic }\end{array}$ \\
\hline & & The Cultural Space of Sosso-Bala & Guinea \\
\hline & & $\begin{array}{l}\text { The Cultural Space of Jemaa el-Fna } \\
\text { Square }\end{array}$ & Morocco \\
\hline & & $\begin{array}{l}\text { The Cultural Space and Oral Culture of } \\
\text { the Semeiskie }\end{array}$ & $\begin{array}{l}\text { Russian } \\
\text { Federation }\end{array}$ \\
\hline & & The Cultural Space of the Boysun District & Uzbekistan \\
\hline \multirow{2}{*}{$\begin{array}{l}\text { The } \\
\text { 2nd } \\
\text { batch }\end{array}$} & \multirow[b]{2}{*}{2003} & The Kihnu Cultural Space & Estonia \\
\hline & & $\begin{array}{l}\text { The Cultural Space of the Yaaral and } \\
\text { Degal }\end{array}$ & Mali \\
\hline \multirow{3}{*}{$\begin{array}{l}\text { The } \\
\text { 3rd } \\
\text { batch }\end{array}$} & \multirow{3}{*}{2005} & $\begin{array}{l}\text { The Cultural Space of Palenque de San } \\
\text { Basilio }\end{array}$ & Colombia \\
\hline & & $\begin{array}{l}\text { The Cultural Space of the Bedu in Petra } \\
\text { and Wadi Rum }\end{array}$ & Jordan \\
\hline & & The Space of Gong Culture & Viet Nam \\
\hline \multirow{2}{*}{$\begin{array}{l}\text { The } \\
5 \text { th } \\
\text { batch }\end{array}$} & \multirow[t]{2}{*}{2009} & $\begin{array}{l}\text { The Candombe and its socio-cultural } \\
\text { space: a community practice }\end{array}$ & Uruguay \\
\hline & & Suiti cultural space in Alsunga & Latvia \\
\hline
\end{tabular}

According to the UNESCO published data sorting

From the Angle of the convention for the Safeguarding of Intangible Cultural Heritage by UNESCO, or from the intangible cultural heritage practice point by the governments all over the world, it all showed that the "cultural space" was an important element in the intangible cultural heritage system. The state council of China also issued the "the interim measures of national intangible cultural heritage representative work", which ruled the specific requirements about "cultural space" in the 3rd chapter 6 parts in the article [8].

So, the Chinese intangible cultural heritage representative list should be with the international trend as soon as possible and create the "cultural space" element as a new type in intangible cultural protection system.

B. Systematic Reorganization of intangible cultural heritage representative list

In the first paragraph of article 2, the UNESCO definition of intangible cultural heritage was oral traditions and expressions, including language as a vehicle of the intangible cultural heritage. From the above definition of UNESCO, the national language was also the 1st type of "the code table of national folk culture protection project survey manual" in China [9]. So, the language was an important component content in the UNESCO representative list of the intangible cultural heritage of humanity.

The inheritance of languages and dialects is a kind of group behaviors. But existence intangible heritage protection works have based on the individual inheritance person and project. The group protection works were a new field, which have some great operating difficulties. On the other side, many minorities gradually gave up national language with Chinese historical process of popularizing mandarin. the "national language" and "folk literature" has not been distinguished in the classification system of Chinese intangible cultural heritage. People often think that myths, legends, stories, songs, epic, proverb and long poem were the language.

So, the Chinese intangible cultural heritage representative list should be optimized on the basis of its historical and social value.

\section{Acknowledgment}

A major program of key research base focused on the humanities and social science of Ministry of Education: Reach on the Construction and Service of Archival Information Resources based on Public Requirement (Grant No. 2009JJD870001)

\section{References}

[1] WANG Wen-zhang, "Overview of intangible cultural heritage. Beijin:Education science press”, PP.15, 2008.

[2] HU Shun-hua, "China national folk literature and art integration books was completed", The Yangtze river daily, page:9,2009-9-7.

[3] KANG Bao-cheng, "The development of Chinese intangible cultural heritage protection(2011)". Beijin: Social science press, PP. 6,2011.

[4] ZHOU He-ping, "We will strengthen the protection of intangible cultural heritage". Beijin:Art critic, PP.6, 2012(2).

[5] Wan Liang, "Don't let the 'intangible' utilitarian". Beijin:Chinese opera PP.17, 2012(06).

[6] ZHOU He-ping, "We will strengthen the protection of intangible cultural heritage". Beijin:Art critic, PP.6, 2012(2).

[7] Electronic Publication: "Text of the Convention for the Safeguarding of Intangible Cultural Heritage", (UNESCO). http://www.unesco.org/culture/ich/index.php? Lg = EN\&pg $=00022$

[8] Electronic Publication: "The interim measures of national intangible cultural heritage representative work", (The State Council of China) http://www.gov.cn/gongbao/content/2005/content_63227.htm.

[9] Chinese National Academy of Arts, "Chinese national folk culture protection project reconnaissance work manual” Beijin:Art critic, PP.19, 2005 . 